\title{
Modulation of hydrogen peroxide induced injury to corneal endothelium by virus mediated catalase gene transfer
}

\author{
T Hudde, R M Comer, M T Kinsella, L Buttery, P J Luthert, J M Polak, A J T George, \\ D F P Larkin
}

See end of article for authors' affiliations

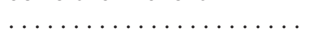

Correspondence to: D F P Larkin, MD,

Moorfields Eye Hospital,

City Road, London

EC1V 2PD, UK;

f.larkin@ucl.ac.uk

Accepted for publication

20 February 2002
Br J Ophthalmol 2002;86:1058-1062

\begin{abstract}
Aim: To examine the effect of catalase gene transfer on survival of corneal endothelial cells (EC) following challenge with hydrogen peroxide $\left(\mathrm{H}_{2} \mathrm{O}_{2}\right)$ in an ex vivo model of oxidative stress.

Methods: A recombinant adenovirus vector $(\mathrm{AdCL}$ ) was used to transfer human catalase cDNA into EC of whole thickness rabbit corneas ex vivo. The resulting catalase protein concentration was measured in corneal lysates by ELISA; catalase functional activity in lysates was determined using a $\mathrm{H}_{2} \mathrm{O}_{2}$ activity assay. To examine the morphological effects of catalase gene transfer in modulation of $\mathrm{H}_{2} \mathrm{O}_{2}$ induced injury, transduced corneas were maintained in ex vivo culture and challenged with $\mathrm{H}_{2} \mathrm{O}_{2}$. Laser scanning confocal microscopy was used to image EC injury. Cell density, cell morphology, and ratios of viable to necrotic cells were determined.

Results: Following incubation with $\mathrm{AdCL}$, catalase expression reached maximum at 5-7 days. Corneas transduced with $\mathrm{AdCL}$ showed increased EC cell survival following challenge with $\mathrm{H}_{2} \mathrm{O}_{2}$ on day 3 when compared to null vector control or mock infected corneas.

Conclusions: Ex vivo catalase gene transfer can protect $\mathrm{EC}$ from death mediated by $\mathrm{H}_{2} \mathrm{O}_{2}$. This gene based approach to the protection of corneal endothelium from oxidative stress may have application in prevention of EC loss in pathological conditions in which $\mathrm{H}_{2} \mathrm{O}_{2}$ is involved and in ex vivo donor corneal storage before transplantation.
\end{abstract}

D eath of corneal endothelial cells (EC), by necrosis and possibly apoptosis, plays a major part in many corneal diseases and in corneal graft failure. ${ }^{1-3}$ Human EC do not undergo mitosis to any significant extent and respond to loss of neighbouring cells by enlargement and spreading. In consequence, EC death results in diminished cell density. If density is reduced below critical levels, the endothelial deturgescent pump fails and aqueous enters the stroma, resulting in oedema and loss of corneal transparency. ${ }^{4}$

Hydrogen peroxide $\left(\mathrm{H}_{2} \mathrm{O}_{2}\right)$ is produced by the cornea and neighbouring tissues. Aqueous humour itself generates $\mathrm{H}_{2} \mathrm{O}_{2}$ with reported maximum levels of approximately $0.09 \mathrm{mM}$ $\mathrm{H}_{2} \mathrm{O}_{2}$ in bovine aqueous. ${ }^{5}$ High intraocular concentrations of reactive oxygen species such as $\mathrm{H}_{2} \mathrm{O}_{2}$ have been found in inflammatory disorders of the eye and are associated with tissue damage. ${ }^{6-8}$ A significant role has been attributed to oxidants in the loss of EC in ageing and in some disease states.

In addition to the significance of EC loss in disease, death of these cells is also a major limiting factor in maintenance of donor corneas ex vivo before transplantation. Falling EC density during storage accounts for about $30 \%$ of corneas being discarded from eye banks, the endothelium being considered of insufficient quality for transplantation. ${ }^{9}$ Both necrosis and apoptosis in endothelium of stored corneas have recently been described, ${ }^{1}{ }^{10}$ indicating that intervention strategies would be required to protect EC from death by both pathways. Oxidative damage to EC by free radicals is one possible cause of cell loss during ex vivo storage. Protection of human vascular endothelium from oxidant injury by adenovirus mediated transfer of the gene encoding human catalase has been shown. ${ }^{11}$ This construct has also been used by Guy et al in suppression of experimental optic neuritis. ${ }^{12}{ }^{13}$

The feasibility of gene transfer to endothelium of corneas ex vivo having been demonstrated in previous reports, ${ }^{14-16}$ in order to examine possible use of gene based approaches to protect EC both during ex vivo storage and following transplantation, we tested the effect of catalase gene transfer on $\mathrm{H}_{2} \mathrm{O}_{2}$ induced cell death.

\section{METHODS}

Recombinant adenovirus vectors

The recombinant adenovirus containing a cDNA sequence encoding human catalase (AdCL) has been previously described. ${ }^{11}$ It is a replication defective recombinant type 5 adenovirus ( $\mathrm{Ad} 5$ ) containing the $2.3 \mathrm{~kb}$ human catalase cDNA (a kind gift of Dr R Crystal, Cornell University, New York, USA). The vector control used was an El deleted Ad5 with no cDNA insert (Ad0, kindly provided by Dr Matthew Wood, University of Oxford, UK).

\section{Virus propagation and purification}

AdCL and Ad0 viruses were propagated in transcomplementing 293 cells as previously described. ${ }^{14}$ In brief, the 293 cells were cultured in DMEM 10\% (v/v) fetal calf serum (FCS, Gibco, Paisley, UK), 2 mM L-glutamine (Flow Labs, Irvine, UK) $100 \mathrm{U} / \mathrm{ml}$ penicillin, and $100 \mu \mathrm{g} / \mathrm{ml}$ streptomycin (Gibco) in 5\% carbon dioxide at $37^{\circ} \mathrm{C}$. At approximately $80 \%$ cell confluence, the culture medium was replaced with medium based on $2 \%$ $(\mathrm{v} / \mathrm{v})$ FCS and inoculated with adenovirus at a multiplicity of infection of approximately 10. When cytopathic effect occurred after 36-48 hours the infected cells were harvested and resuspended in 1/50th of volume of culture supernatant. Virus was released from the infected cells by three freeze-thaw cycles. The virus was purified by two rounds of caesium chloride (Boehringer Mannheim, Lewes, UK) density gradient centrifugation. The virus preparation was passed through a 0.2 $\mu \mathrm{m}$ filter and stored at $-70^{\circ} \mathrm{C}$. Virus titres were determined by a plaque assay to be $5 \times 10^{9}$ plaque forming units $(\mathrm{pfu}) / \mathrm{ml}$ and $10^{10} \mathrm{pfu} / \mathrm{ml}$ for AdCL and Ad0, respectively. 


\section{Corneal culture and transduction conditions}

Corneas of New Zealand white rabbits were excised with a thin scleral rim and were cut into quarters, particular care being taken to minimise instrumental damage to the endothelium. For transduction, corneal specimens were placed into a 96 well plate, and incubated at $37^{\circ} \mathrm{C}$ in $5 \%$ carbon dioxide in $250 \mu \mathrm{l}$ medium (MEM supplemented with $2 \%$ FCS, $2 \mathrm{mM}$ L-glutamine, $100 \mathrm{U} / \mathrm{ml}$ penicillin, and $100 \mu \mathrm{g} / \mathrm{ml}$ streptomycin) containing adenoviruses at different concentrations or no virus (mock infected negative controls). After 3 hours the samples were washed three times in PBS, transferred into a 24 well plate and $2 \mathrm{ml}$ medium (MEM supplemented with $10 \%$ FCS, $2 \mathrm{mM}$ L-glutamine, $100 \mathrm{U} / \mathrm{ml}$ penicillin, and 100 $\mu \mathrm{g} / \mathrm{ml}$ streptomycin) added. Medium was replaced on day 1 and subsequently every second day.

\section{Exposure to $\mathrm{H}_{2} \mathrm{O}_{2}$}

Rabbit corneal specimens were washed three times in PBS and placed endothelial side up in wells of a 24 well plate and covered with $995 \mu \mathrm{l}$ of medium (MEM without FCS, supplemented with $2 \mathrm{mM}$ L-glutamine, $100 \mathrm{U} / \mathrm{ml}$ penicillin, and 100 $\mu \mathrm{g} / \mathrm{ml}$ streptomycin). Five $\mu \mathrm{l}$ of $100 \mathrm{mM} \mathrm{H}_{2} \mathrm{O}_{2}$ stock solution was added and mixed by pipetting up and down three times with a $1 \mathrm{ml}$ pipette (final concentration $0.5 \mathrm{mM} \mathrm{H}_{2} \mathrm{O}_{2}$ ). The corneas were incubated for 16 hours at $37^{\circ} \mathrm{C}$ and $5 \%$ carbon dioxide and then examined by laser scanning confocal microscopy.

\section{Preparation of corneal lysates}

Transduced quarter corneas were washed five times with PBS before incubation with $1 \mathrm{ml}$ of $40 \mathrm{mM}$ TRIS-HCl, pH 7.5, $1 \mathrm{mM}$ $\mathrm{NaCl}$ for 5 minutes at $4^{\circ} \mathrm{C}$. After centrifugation at $14000 \mathrm{rpm}$ (Jouan microfuge, Cedex, France) at $4^{\circ} \mathrm{C}$ for 10 minutes, the supernatant was discarded and $120 \mu \mathrm{l}$ of 0.25 TRIS-HCl (pH 8.0) added. Corneal cells including epithelium, keratocytes and endothelium were lysed by three freeze-thaw cycles and the supernatants containing the cytoplasmic contents of the cells were aliquoted and stored at $-20^{\circ} \mathrm{C}$.

\section{Competitive ELISA for catalase}

A competitive ELISA was used as previously described ${ }^{18}$ to determine catalase levels in transduced cells. Briefly, a 96 well plate was coated with $1 \mathrm{U} /$ well human erythrocyte catalase (Sigma, Poole, UK) and the substrate blocked with 1\% BSA in PBS. Cell lysates obtained from either untransduced cells or cells transduced with catalase cDNA were mixed with rabbit anti-human erythrocyte catalase antibody (Calbiochem, San Diego, USA) at 1/10 000 dilution, and after 30 minutes of incubation at $37^{\circ} \mathrm{C}, \mathrm{Ag}$-Ab mixtures were added to wells of the ELISA plate and incubated for further 1 hour. After washing, biotinylated goat anti-rabbit IgG antibody (Dako, Denmark) was added at 1/20 000 dilution. After 1 hour's incubation, extrAVIDIN (Sigma) at 1/1000 dilution was added to each well and incubated for 30 minutes. Following each step the wells were washed four times with PBS/0.1\% Tween-20. Reactions were developed by using OPD substrate and stopped by addition of $2 \mathrm{M} \mathrm{H}_{2} \mathrm{SO}_{4}$. Plates were examined in a microplate reader at $492 \mathrm{~nm}$ absorbance. Catalase levels were determined by reference to a standard curve made with serial dilutions of human erythrocyte catalase. Values given below in units of enzyme activity can be converted into $\mu \mathrm{g}$ by the equation: 64.4 $\mathrm{U}=1 \mu \mathrm{g}$.

\section{Catalase activity assay}

Catalase activity was determined by consumption of $\mathrm{H}_{2} \mathrm{O}_{2}$ with a spectrophotometric assay using o-dianisidine dihydrochloride (o-DD, Sigma). Samples ( $100 \mu \mathrm{l}$ ) of corneal lysates were prepared in distilled water ( $1: 4$ dilution) and incubated with $400 \mu \mathrm{l}$ of $0.6 \mathrm{mM} \mathrm{H}_{2} \mathrm{O}_{2}$ for 10 minutes at room temperature. The reaction was stopped by adding $100 \mu \mathrm{l}$ of $6 \mathrm{mM}$ sodium
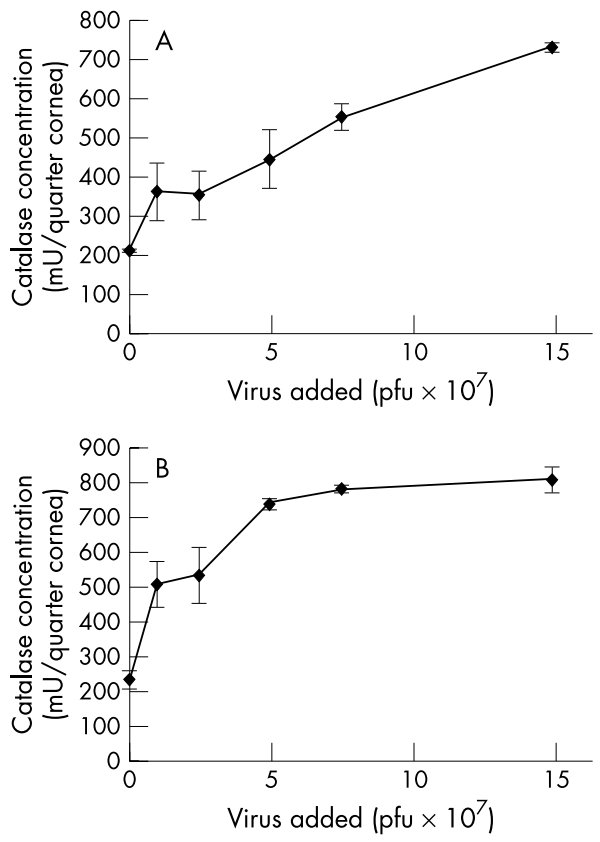

Figure 1 Optimisation of virus concentration for gene transfer. Corneal samples were transduced with up to $1.5 \times 10^{8} \mathrm{pfu} \mathrm{AdCL}$ per triplicate specimen. Assays were repeated twice with consistent results. Mean values (SD) from one assay are shown. (A) Catalase quantification by ELISA. The amount of catalase detected by ELISA increased with the amount of $\mathrm{AdCL}$ virus applied, reaching $730 \mathrm{mU}$ after incubation with $1.5 \times 10^{8} \mathrm{pfu}$. (B) Catalase quantification by $\mathrm{H}_{2} \mathrm{O}_{2}$ activity assay. Corneal samples were infected with up to $1.5 \times$ $10^{8} \mathrm{pfu} \mathrm{AdCL}$. The amount of catalase enzyme detected by ELISA increased with the amount of $\mathrm{AdCL}$ virus applied, reaching $795 \mathrm{mU}$ after incubation with $1.5 \times 10^{8} \mathrm{pfu}$. The curve reached a plateau at approximately $5 \times 10^{7} \mathrm{pfu} \mathrm{AdCL}$.

azide (Sigma) before incubation with $2 \mathrm{ml}$ of o-DD solution ( $5 \%$ FCS, $100 \mathrm{mg} / \mathrm{ml}$ gentamicin sulphate (Sigma) $80 \mathrm{mg} / \mathrm{ml}$ o-DD in Eagle's MEM without phenol red) and $10 \mu \mathrm{l}$ of 1000 U horseradish peroxidase type IV (Sigma) $/ \mathrm{ml} \mathrm{dH}_{2} \mathrm{O}$ for 1 hour at $37^{\circ} \mathrm{C}$. Finally, $150 \mu \mathrm{l}$ of each reaction was transferred to individual wells of a flat bottomed 96 well ELISA plate. Absorbance was read at $470 \mathrm{~nm}$ using a microplate reader. Catalase activities were determined by reference to a standard curve constructed with serial dilutions of human erythrocyte catalase.

\section{Laser scanning confocal microscopy}

Rabbit corneas were cut in quarters, infected with AdCL, and either incubated with $\mathrm{H}_{2} \mathrm{O}_{2}$ or left untreated as controls. Corneal specimens were transferred to a vital staining solution containing propidium iodide (PI, $50 \mu \mathrm{g} / \mathrm{ml}$, red in fluorescence light) and acridine orange ( $\mathrm{AO}, 25 \mu \mathrm{g} / \mathrm{ml}$, green in argon fluorescence light) and imaged by confocal microscopy (Bio-Rad MRC 600, fitted with an argon laser), as described by Wusteman et al. ${ }^{19}$ Viable EC exclude PI and therefore appear green because of AO staining. Necrotic cells have a permeable cell membrane which cannot exclude PI: this results in red fluorescent nuclear staining on account of displacement of AO from DNA. Where necessary a z-plane series was carried out to adjust for the undulating endothelial surface.

\section{Statistical analysis}

Data are expressed as the mean (SD) of triplicate samples. The Mann-Whitney $U$ test was used to determine the significance of differences between the means of treated and untreated groups. 

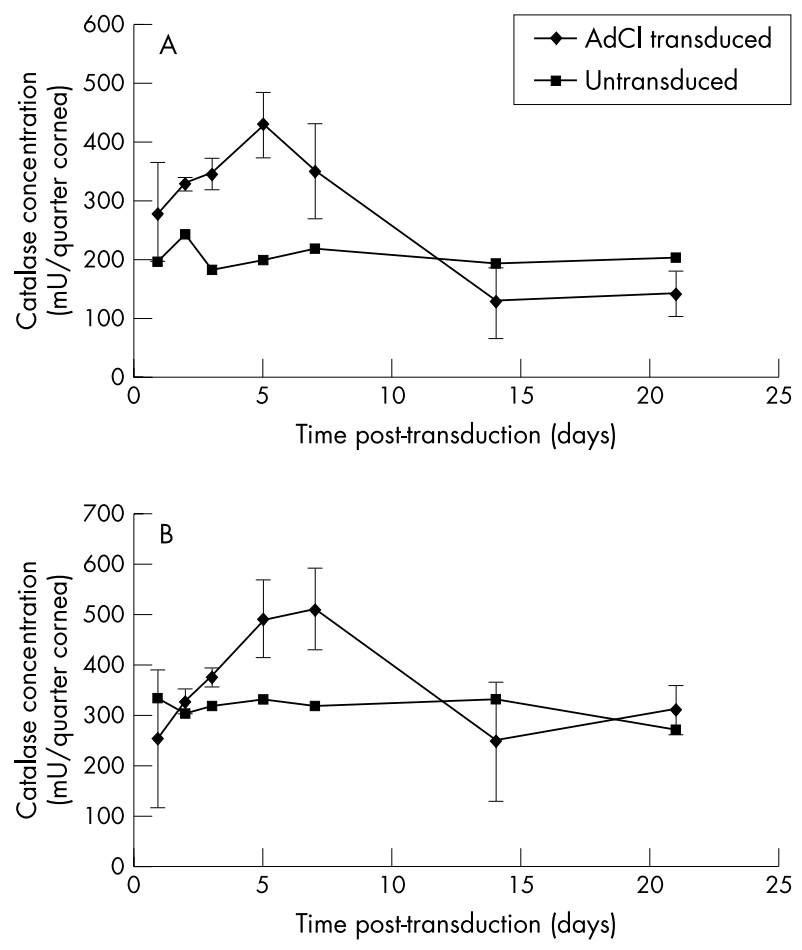

Figure 2 Kinetics of catalase production. Corneal lysates were prepared at intervals from 1 to 21 days following gene transfer. Catalase secretion into culture medium from triplicate specimens was quantified by (A) ELISA and (B) $\mathrm{H}_{2} \mathrm{O}_{2}$ activity assay. Mean values (SD) from one assay are shown. In both assays, highest levels of catalase were detected 5-7 days after transduction.

\section{RESULTS}

\section{Optimisation of virus concentrations for gene transfer}

\section{Catalase concentrations}

Triplicate corneal specimens transduced with $0,10^{7}, 2.5 \times 10^{7}$, $5 \times 10^{7}, 7.5 \times 10^{7}$, and $1.5 \times 10^{8}$ pfu per specimen AdCL were analysed for catalase production by ELISA after an interval of 3 days. The assay was repeated twice with consistent results. The dose-response curve reached a maximum of $730 \mathrm{mU}$ per sample with $1.5 \times 10^{8}$ pfu AdCL (Fig 1A). In previous experiments, corneas which had been transduced with Ad0 and untransduced corneas were examined: no increased expression of catalase was detected in lysates of these corneas (data not shown). It should be noted that negative controls contained catalase. The background levels of catalase are a consequence of endogenous enzyme levels in the cornea (including that contained in epithelial cells and keratocytes as well as EC).

\section{Catalase activity}

Triplicate corneal specimens were transduced with up to $1.5 \times$ $10^{8}$ pfu AdCL as described above; corneal lysates were prepared and examined by the $\mathrm{H}_{2} \mathrm{O}_{2}$ activity assay. The assay was repeated twice with consistent catalase activity results. Activity increased with the amount of AdCL virus applied, reaching $795 \mathrm{mU}$ after incubation with $1.5 \times 10^{8} \mathrm{pfu}$. The dose-response curve reached a plateau at approximately $5 \times$ $10^{7} \mathrm{pfu}$ of AdCL (Fig lB). No increased expression of catalase was detected in lysates of Ad0 infected corneas compared to mock infected corneas (data not shown). The higher levels of endogenous catalase detected in the negative controls by the activity assay reflect the reduced sensitivity of the ELISA (specific for human catalase) to detect rabbit catalase when compared to the activity assay.

\section{Kinetics of catalase production \\ Concentration profile}

Rabbit corneal specimens (quarter corneas) were transduced with $2.5 \times 10^{7} \mathrm{pfu}$ AdCL as described above. This concentration of virus as chosen as it was just below that which produced maximal expression in the titration described above. From each cornea, three quarters were transduced by virus and one was incubated in virus-free medium. Triplicate specimens were incubated for up to 21 days, cell lysates prepared, and the concentration of catalase determined by ELISA. A peak concentration of catalase protein was reached on day 5 with $420 \mathrm{mU} /$ quarter cornea (Fig 2A).

\section{Catalase activity assay}

Corneal lysates prepared as above for the ELISA time course were used in the catalase activity assay. Corneal specimens were transduced with $2.5 \times 10^{7}$ pfu AdCL and cell lysates analysed from 1 to 21 days. Peak activity was detected at days $5-7$, with 490 and $510 \mathrm{mU}$ per sample respectively. At 14 days, no significant difference was found compared to negative controls (Fig 2B).

\section{Imaging of EC and exposure to $\mathrm{H}_{2} \mathrm{O}_{2}$}

Confocal microscopy was used to assess the number of viable and necrotic cells, as well as cell morphology, in intact corneas (Fig 3A-C). These were then used to optimise the dose and incubation time with $\mathrm{H}_{2} \mathrm{O}_{2}$. In most experiments we chose to
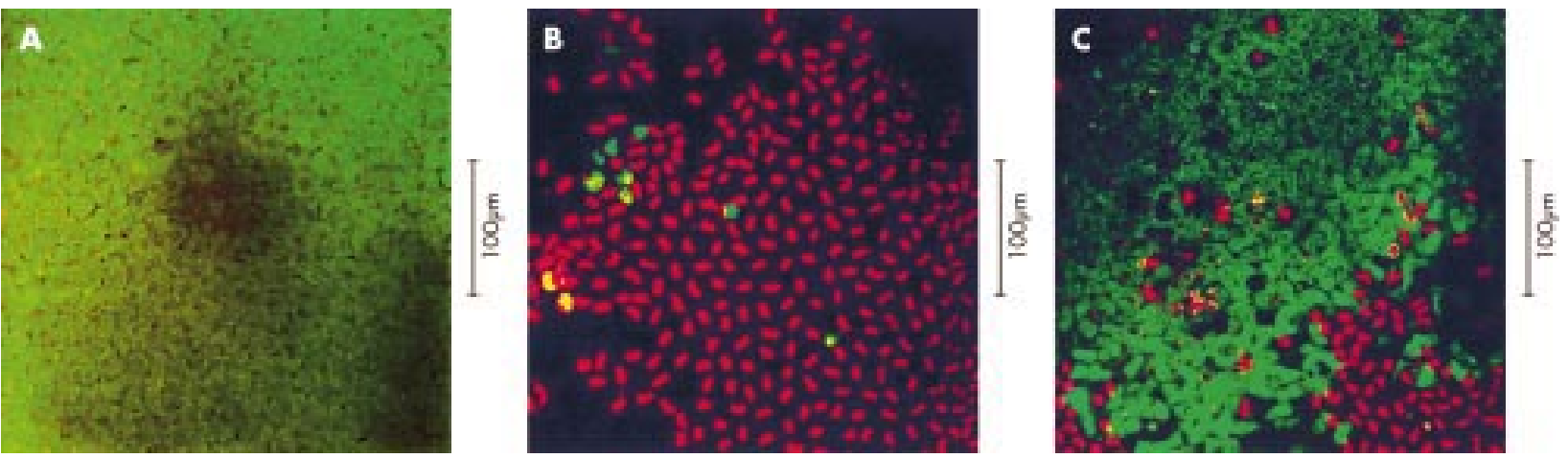

Figure 3 (A) Unmodified rabbit corneal endothelium, which had not been exposed to $\mathrm{AdCL}$ or $\mathrm{H}_{2} \mathrm{O}_{2}$ challenge, stained with acridine orange (green) and propidium iodide (red, as shown in fluorescent light). (B) Rabbit corneal endothelium which had been infected with $2.5 \times 10^{7} \mathrm{pfu}$ Ad0 per corneal sample, before incubation with $0.5 \mathrm{mM} \mathrm{H}_{2} \mathrm{O}_{2}$ for 16 hours. Propidium iodide (red) displaces acridine orange. Most cells are necrotic because of toxicity of $\mathrm{H}_{2} \mathrm{O}_{2}$. Dark areas in this image and $(\mathrm{C})$ correspond to foci of cell loss, confirmed on haematoxylin and eosin staining (not shown). (C) Rabbit corneal endothelium which had been infected with $2.5 \times 10^{7}$ pfu AdCL per specimen before incubation with $0.5 \mathrm{mM} \mathrm{H}_{2} \mathrm{O}_{2}$ for 16 hours. Most of the cells exclude propidium iodide and appear green, indicating viability. Cell morphology is altered compared to that shown in (A), suggesting some degree of $\mathrm{H}_{2} \mathrm{O}_{2}$ induced cell damage. 

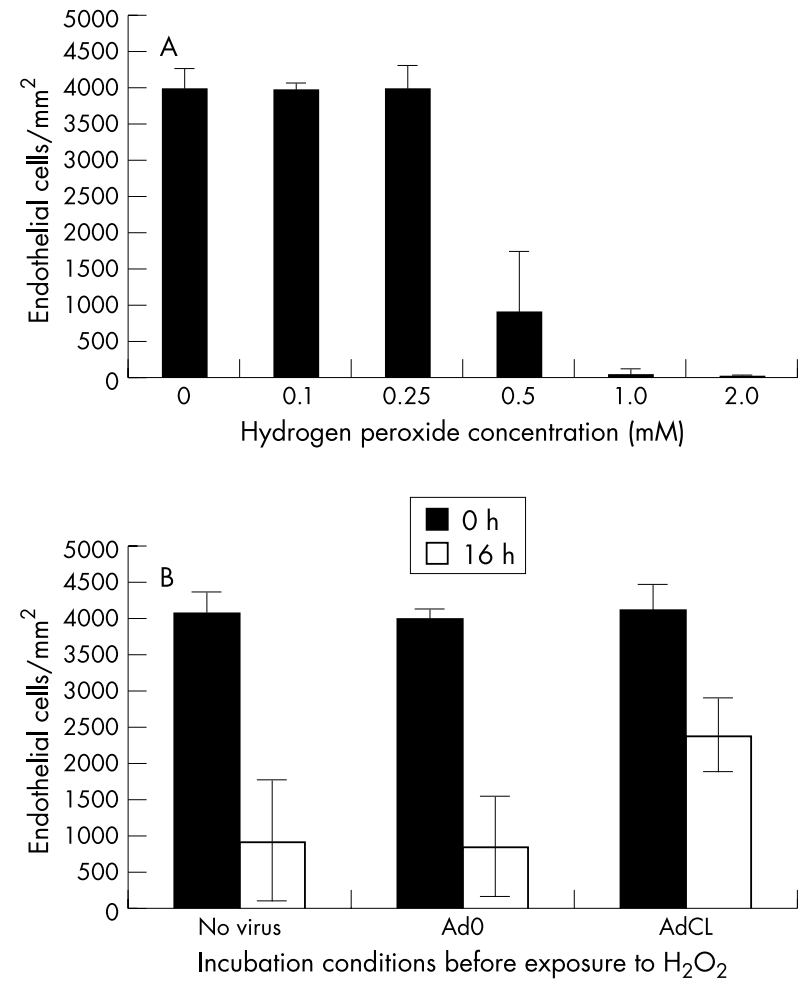

Figure 4 Changes in corneal endothelial cell (EC) density following exposure to $\mathrm{H}_{2} \mathrm{O}_{2}$.. EC density was quantified by laser scanning confocal microscopy. Mean values (SD) from triplicate specimens in one representative experiment are shown. (A) Concentration dependent damage to $\mathrm{EC}$ following incubation of corneas in $\mathrm{H}_{2} \mathrm{O}_{2}$ at concentrations ranging from $0.1 \mathrm{mM}$ to $2.0 \mathrm{mM}$ for 16 hours. (B) Viability of EC was determined with scanning laser confocal microscopy in $\mathrm{AdCL}$ infected $\left(2.5 \times 10^{7} \mathrm{pfu}\right)$, $\mathrm{AdO}(2.5 \times$ $\left.10^{7} \mathrm{pfu}\right)$, and mock infected corneal specimens. After 16 hours of incubation in $0.5 \mathrm{mM} \mathrm{H}_{2} \mathrm{O}_{2}$, significantly more $\mathrm{EC}$ were viable in the AdCL transduced group.

use concentrations of $\mathrm{H}_{2} \mathrm{O}_{2}$ of $0.1-2.0 \mathrm{mM}$, as these are physiologically relevant. ${ }^{5}$ We assessed cell injury and death after 16 hours, as at earlier times no loss of ECs was seen. As can be seen in a representative experiment, incubation with $0.5 \mathrm{mM}$ $\mathrm{H}_{2} \mathrm{O}_{2}$ resulted in massive cell death in untransduced corneas (Fig 4A). However, corneas transduced with AdCL before exposure to $\mathrm{H}_{2} \mathrm{O}_{2}$ showed a clear increased survival of EC compared to mock infected samples and samples transduced with Ad0 $(\mathrm{p}<0.05)$ (Fig 4B). No protective effect of AdCL was seen following shorter exposure, ranging from 1 to 8 hours, of corneal specimens to $\mathrm{H}_{2} \mathrm{O}_{2}$ at concentrations of up to $10 \mathrm{mM}$.

It is noteworthy that $2.5 \times 10^{7} \mathrm{pfu}$ AdCL induces a twofold to fourfold increase in catalase levels on the assays, but a more striking effect on endothelial protection. This apparent discrepancy is explained by the fact that catalase in epithelium and stroma as well as endothelium is measured in the assays, while on the other hand the increase in catalase concentration found following exposure to AdCL is almost entirely from endothelium, as adenovirus vectors have been shown to transduce endothelium only. ${ }^{14}$ The concentration of catalase in the endothelium will therefore be increased by transduction with adenovirus to a greater extent than suggested by assays measuring total corneal catalase, resulting in an enhanced protective effect.

\section{DISCUSSION}

Results of the ELISA and $\mathrm{H}_{2} \mathrm{O}_{2}$ activity assay demonstrate that the cornea can express high concentrations of biologically active human erythrocyte catalase after transduction using an adenoviral construct. Previous work on whole cornea using adenoviral mediated transfer of a histochemical marker gene indicates that this vector transduces the endothelium only. ${ }^{14}$ This catalase expression was shown to protect EC from cytotoxic effects of $\mathrm{H}_{2} \mathrm{O}_{2}$. The $\mathrm{H}_{2} \mathrm{O}_{2}$ might be exerting its toxic effect by oxidative damage either intracellularly or on the cell surface. As catalase is expressed within the cell one might expect that it is more effective in protection against intracellular damage, and that surface structures of the endothelial cells might be damaged before $\mathrm{H}_{2} \mathrm{O}_{2}$ is degraded within the cell.

Previous work has indicated that low concentrations (250$500 \mu \mathrm{M}$ ) of $\mathrm{H}_{2} \mathrm{O}_{2}$ can induce apoptosis in some cell types. ${ }^{20}$ To investigate whether $\mathrm{H}_{2} \mathrm{O}_{2}$ induces apoptosis rather than oxidative injury and necrosis in corneal EC, we examined corneas with light, electron, and laser confocal microscopy combined with Annexin V and PI staining or with TUNEL assay for intervals up to 3 days following incubation with a range of $\mathrm{H}_{2} \mathrm{O}_{2}$ concentrations. By these methods, apoptosis could not be detected (data not shown). These findings suggest that the morphological changes found after $\mathrm{H}_{2} \mathrm{O}_{2}$ challenge are not a result of cell death by apoptosis.

Oxidative stress as a pathological feature in many corneal disorders might be treatable or preventable with gene based approaches. In the context of corneal transplantation, gene therapy strategies aimed at preventing corneal allograft failure have relied on the expression of immunomodulatory proteins. ${ }^{152122}$ The approach outlined here has a different goal-namely, protection of the target tissue from death induced by the immune response or the stress of the grafting procedure. Similar strategies have been applied to hepatic transplantation, with the expression of both antioxidant and anti-apoptotic genes being used to reduce damage to grafts following transplantation. ${ }^{23}{ }^{24}$ Damage to endothelium by oxidative stress may also be important in ex vivo donor corneal storage before transplantation. Prevention or even attenuation of endothelial injury in this setting would have major benefits in eye banking as it would result in (i) fewer donor corneas discarded on account of insufficient endothelial cell density following storage, and (ii) augmented endothelial function in donor corneas in vivo following transplantation. The causes of oxidative stress can include not only exogenous reactive oxygen intermediates, such as $\mathrm{H}_{2} \mathrm{O}_{2}$, but also agents that induce the intracellular production of such molecules. For example, expression of catalase has been shown to protect cells from apoptosis induced by the cancer chemotherapy agent, cisplatin. ${ }^{20}$

It is axiomatic that the benefit of a gene based approach to cell protection would depend on an acceptably low level of cytopathogenicity and immunogenicity caused by the vector for gene transfer. In the studies described above, a null adenovirus vector control Ad0 was included in experiments to indicate any virus specific endothelial cell injury. However, it is clear that if gene based approaches to modulation of oxidative stress are to become useful in clinical practice, non-viral vectors or recombinant viruses with more extensive deletion of virus genes will be used, ${ }^{25-27}$ not least to minimise the immune response to virus infected EC following transplantation into a recipient eye. The kinetics of catalase production, with maximum levels detected at 5-7 days following exposure to virus vector, are similar to those reported in other studies of ex vivo adenovirus mediated gene transfer to the cornea. ${ }^{1421}$ For application of this approach in corneal storage before transplantation, longer term expression of catalase would also be desirable in order to allow EC protection during longer periods of ex vivo maintenance and in the earliest days in vivo following transplantation. This is likely to become feasible with further vector development.

\section{ACKNOWLEDGEMENTS}

Supported by Deutsche Forschungsgemeinschaft (grant Hu 761/1-1), the Wellcome Trust (project grant 050966), and Moorfields Eye Hospital locally organised research scheme (grant 439). 


\section{Authors' affiliations}

T Hudde, P J Luthert, D F P Larkin, Department of Pathology, Institute of Ophthalmology, University College London, UK

T Hudde, R M Comer, M T Kinsella, A J T George, D F P Larkin, Department of Immunology, Division of Medicine, Faculty of Medicine, Imperial College of Science, Technology and Medicine, London, UK

L Buttery, J M Polak, Department of Histochemistry, Division of Investigative Sciences, Faculty of Medicine, Imperial College of Science, Technology and Medicine, London, UK

\section{REFERENCES}

1 Albon J, Tullo AB, Aktar S, et al. Apoptosis in the endothelium of human corneas for transplantation. Invest Ophthalmol Vis Sci 2000;41:2887-93

2 Larkin DFP, Alexander RA, Cree IA. Infiltrating inflammatory cell phenotypes and apoptosis in rejected human corneal allografts. Eye 1997;11:68-74.

3 Cho KS, Lee EH, Choi JS, et al. Reactive oxygen species-induced apoptosis and necrosis in bovine corneal endothelial cells. Invest Ophthalmol Vis Sci 1999;40:911-9.

4 Dikstein S, Maurice DM. The metabolic basis to the fluid pump in the cornea. J Physiol (Lond) 1972;221:29-41.

5 Spector A, Ma W, Wang RR. The aqueous humor is capable of generating and degrading $\mathrm{H}_{2} \mathrm{O}_{2}$. Invest Ophthalmol Vis $\mathrm{SC}$ 1998;39:1 188-97.

6 Wu GS, Zhang J, Rao NA. Peroxynitrite and oxidative damage in experimental autoimmune uveitis. Invest Ophthalmol Vis $\mathrm{Sci}$ 1997:38:1333-9.

7 Rose RC, Richer SP, Bode AM. Ocular oxidants and antioxidant protection. Proc Soc Exp Biol Med 1998;217:397-407.

8 Green K. Free radicals and aging of anterior segment tissues of the eye: a hypothesis. Ophthalmic Res 1995;27:143-9.

9 Armitage WJ, Easty DL. Factors influencing the suitability of organ-cultured corneas for transplantation. Invest Ophthalmol Vis Sci 1997;38: 16-24

10 Komuro A, Hodge DO, Gores GJ, et al. Cell death during corneal storage at 4 degrees C. Invest Ophthalmol Vis Sci 1999:40:2827-32.

11 Erzurum SC, Lemarchand $P$, Rosenfeld MA, et al. Protection of human endothelial cells from oxidant injury by adenovirus-mediated transfer of the human catalase cDNA. Nucleic Acids Research 1993;21:1607-12.
12 Guy J, Qi X, Hauswirth WW. Adeno-associated viral-mediated catalase expression suppresses optic neuritis in experimental allergic encephalitis. Proc Natl Acad Sci USA 1998;95:13847-52

13 Guy J, Qi X, Wang H, Hauswirth WW. Adenoviral gene transfer with catalase suppresses experimental optic neuritis. Arch Ophthalmol 1999:117:1533-9.

14 Larkin DFP, Oral HB, Ring C, et al. Adenovirus-mediated gene delivery to the corneal endothelium. Transplantation 1996;61:363-70

15 Oral HB, Larkin DFP, Fehervari Z, et al. Ex vivo adenovirus-mediated gene transfer and immunomodulatory protein production in human cornea. Gene Ther 1997:4:639-47.

16 Ritter T, Vogt K, Rieck P, et al. Adenovirus-mediated gene transfer of IL-4 to corneal endothelial cells and organ-cultured corneas leads to high IL-4 expression. Exp Eye Res 1999;69:563-8.

17 Byrnes AP, Rusby JE, Wood M, et al. Adenovirus gene transfer causes inflammation in the brain. Neuroscience 1995;66:1015-24.

18 Oral HB, Arancibia-Carcamo CV, Haskard DO, et al. A method for determining the cytoprotective effect of catalase in transiently transfected cell lines and in corneal tissue. Anal Biochem 1999;267:196-202.

19 Wusteman MC, Boylan S, Pegg DE. Cryopreservation of rabbit corneas in dimethyl sulfoxide. Invest Ophthalmol Vis Sci 1997;38:1934-43

20 Oral HB, George AJT, Haskard DO. Prevention of hydrogen peroxide and cisplatin induced apoptosis by intracellular catalase overexpression. Turk J Biol 2000;24:685-96.

21 Rayner SA, Larkin DFP, George AJT. TNF receptor secretion after ex vivo adenoviral gene transfer to cornea and effect on in vivo graft survival. Invest Ophthalmol Vis Sci 2001;42:1568-73.

22 Klebe S, Sykes PJ, Coster DJ, et al. Prolongation of sheep corneal allograft survival by ex vivo transfer of the gene encoding interleukin-10. Transplantation 2001;71:1214-20.

23 Lehmann TG, Wheeler MD, Schwabe RF, et al. Gene delivery of $\mathrm{Cu} / \mathrm{Zn}$-superoxide dismutase improves graft function after transplantation of fatty livers in the rat. Hepatology 2000;32:1255-64

24 Bilbao G, Contreras JL, Gomez-Navarro J, et al. Genetic modification of liver grafts with an adenoviral vector encoding the $\mathrm{Bcl}-2$ gene improves organ preservation. Transplantation 1999:67:775-83.

25 Hudde T, Rayner SA, Comer RM, et al. Activated polyamidoamine dendrimers, a non-viral vector for gene transfer to the corneal endothelium. Gene Ther 1999;6:939-43.

26 Hart SL, Arancibia Carcamo CV, Wolfert MA, et al. Lipid-mediated enhancement of transfection by a nonviral integrin-targeting vector. Hum Gene Ther 1998;9:575-85.

27 Tan PH, King WJ, Chen D, et al. Transferrin receptor-mediated gene transfer to the corneal endothelium. Transplantation 2001;71:552-60. 